\title{
OPEN The response of potato tuber yield, nitrogen uptake, soil nitrate nitrogen to different nitrogen rates in red soil
}

\author{
Kailou Liu ${ }^{1,3 \bowtie}$, Jiangxue Du ${ }^{2,3}$, Yijun Zhong ${ }^{1}$, Zhe Shen ${ }^{2}$ \& Xichu Yu ${ }^{1}$
}

Nutrient-deficient red soil found in the southern region of China is increasingly being used for potato crops to meet the demand for this staple food. The application of nitrogen fertilizer is necessary to support the production of higher tuber yields; however, the links between nitrate nitrogen and the nitrogen balance in red soil are unknown. A field experiment was conducted in Jiangxi Province in 2017 and 2018 to determine the effects of different nitrogen application rates, $0 \mathrm{~kg} \mathrm{ha}^{-1}$ (N0), $60 \mathrm{~kg} \mathrm{ha}^{-1}$ (N60), $120 \mathrm{~kg} \mathrm{ha}^{-1}$ (N120), $150 \mathrm{~kg} \mathrm{ha}^{-1}$ (N150), $180 \mathrm{~kg} \mathrm{ha}^{-1}$ (N180), $210 \mathrm{~kg} \mathrm{ha}^{-1}$ (N210), and $240 \mathrm{~kg} \mathrm{ha}^{-1}$ (N240, the highest rate used by local farmers), on potatoes growing in red soil. Data on tuber yield, crop nitrogen uptake, and the apparent nitrogen balance from the different treatments were collected when potatoes were harvested. Additionally, the content and stock of nitrate nitrogen at different soil depths were also measured. Nitrogen fertilization increased tuber yield but not significantly at application rates higher than $150 \mathrm{~kg} \mathrm{ha}^{-1}$. We estimated that the threshold rates of nitrogen fertilizer application were $191 \mathrm{~kg} \mathrm{ha}^{-1}$ in 2017 and $227 \mathrm{~kg} \mathrm{ha}^{-1}$ in 2018, where the respective tuber yields were 19.7 and $20.4 \mathrm{t} \mathrm{ha}^{-1}$. Nitrogen uptake in potato in all nitrogen fertilization treatments was greater than that in NO by $61.2-237 \%$ and $76.4-284 \%$ in 2017 and 2018, respectively. The apparent nitrogen surplus (the amount of nitrogen remaining from any nitrogen input minus nitrogen uptake) increased with increasing nitrogen application rates. The nitrate nitrogen stock at a soil depth of $0-60 \mathrm{~cm}$ was higher in the 210 and $240 \mathrm{~kg} \mathrm{ha}^{-1}$ nitrogen rate treatments than in the other treatments. Moreover, double linear equations indicated that greater levels of nitrogen surplus increased the nitrate nitrogen content and stock in soils at 0-60 cm depths. Therefore, we estimate that the highest tuber yields of potato can be attained when $191-227 \mathrm{~kg} \mathrm{ha}^{-1}$ nitrogen fertilizer is applied to red soil. Thus, the risk of nitrate nitrogen leaching from red soil increases exponentially when the apparent nitrogen balance rises above $94.3-100 \mathrm{~kg} \mathrm{ha}^{-1}$.

As the fourth most important staple in the global food supply, potato (Solanum tuberosum) crops are grown in many countries ${ }^{1}$, such as China, India, Russia, Ukraine, and the United States of America. Currently, China is the largest potato producer in the world ${ }^{2}$. China's potato crops are mainly planted in its western provinces, such as Gansu, Inner Mongolia, Ningxia, Sichuan and Yunnan ${ }^{3}$, as well as its southern region. However, the planting acreage is smaller and the tuber yield is lower in the southern region than in the western region ${ }^{4}$. The differences may be attributed to poor soil fertility, especially in red soils primarily located in the southern region ${ }^{5}$. Therefore, we aimed to improve potato production in the red soils of southern China through reasonable fertilizer management.

In red soil, nitrogen loss is high due to local rainfall patterns and soil erosion ${ }^{6,7}$. Many researchers have reported that more precise control of the total amount of applied nitrogen fertilizer could be an important measure for decreasing soil nitrogen $\operatorname{loss}^{8,9}$ and the apparent nitrogen balance (the positive or negative value calculated from nitrogen input minus nitrogen uptake). High nitrogen inputs will likely increase the apparent nitrogen balance of soils ${ }^{10}$ and result in greater accumulation of nitrate nitrogen in soil ${ }^{11,12}$ and thus higher nitrogen pollution risk. In the cultivation of major cereals (maize, wheat and rice), "there are large opportunities

\footnotetext{
${ }^{1}$ Jiangxi Institute of Red Soil, National Engineering and Technology Research Center for Red Soil Improvement, Nanchang 331717, People's Republic of China. Institute of Agricultural Resources and Regional Planning, Chinese Academy of Agricultural Sciences, Beijing 100081, People's Republic of China. ${ }^{3}$ These authors contributed equally: Kailou Liu and Jiangxue Du. ${ }^{凶}$ email: liukailou@126.com
} 
to reduce the environmental impact of agriculture by eliminating nutrient overuse (especially nitrogen), while still allowing an approximately $30 \%$ increase in production"13.

For potato production, the threshold rates of nitrogen fertilizer have been reported from studies conducted in the western region of China and other countries. For example, an average rate of $240 \mathrm{~kg} \mathrm{ha}^{-1}$ nitrogen applied to fields in Northwest China ${ }^{14}$ and a lower rate of $200 \mathrm{~kg} \mathrm{ha}^{-1}$ applied to fields in northern China ${ }^{15}$ achieved the highest yields of potato tubers. In the Columbia Basin in the Pacific Northwest of the United States, the optimum rate of nitrogen fertilizer for potato was $336 \mathrm{~kg} \mathrm{ha}^{-111}$. In Florida, U.S.A., Rens et al. ${ }^{16}$ determined that different application rates at different stages of potato growth achieved the highest tuber yield: $114-138 \mathrm{~kg} \mathrm{ha}^{-1}$ nitrogen at emergence and $56 \mathrm{~kg} \mathrm{ha}^{-1}$ nitrogen at tuber initiation. Moreover, the response of potato yield to nitrogen rate may differ due to the potato variety ${ }^{17}$. Reportedly, the tuber yield of heritage potato would be decreased under a nitrogen application rate greater than $80 \mathrm{~kg} \mathrm{ha}^{-1}$ nitrogen, but the tuber yield of modern potato yield can be increased ${ }^{18}$. These potato studies did not investigate crops grown in red soil; however, determining ideal rates of nitrogen fertilizer application to red soil for achieving high yields of potato while reducing nitrogen pollution is needed. This is because nitrate nitrogen easily leaches from red soils due to abundant rainfall and high soil erosion, which elevates the importance of developing more sustainable fertilization strategies in fields with red soil.

A threshold rate of nitrogen fertilizer application to improve the nitrogen use efficiency of potatoes grown in red soils was the focus of our study. A field experiment testing nitrogen fertilizer rates and determining their effects on potato was conducted in red soil from 2017 to 2018. Yield, nitrogen uptake and apparent nitrogen balance data were analysed, and the relationship between the nitrate nitrogen stock and apparent nitrogen balance was discussed. Using the system of a potato crop grown in red soil, the objectives of this study were 1) to determine the threshold rate of nitrogen fertilizer application to achieve high tuber yield, 2) to investigate the changes in the nitrate nitrogen content and stock under different nitrogen fertilizer rates, and 3) to determine the relationship between the nitrate nitrogen stock and apparent nitrogen balance. Overall, the results will provide valuable empirical evidence to help improve potato production in red soils in China.

\section{Materials and methods}

Site description. The field experiment was performed in Xiaojiang Village in the town of Zhanggong, Jinxian County, Jiangxi Province, China $\left(28^{\circ} 35^{\prime} 24^{\prime \prime} \mathrm{N}, 116^{\circ} 17^{\prime} 60^{\prime \prime} \mathrm{E}\right)$. This area has a typical subtropical climate with a mean annual precipitation of $1,727 \mathrm{~mm}$ and a mean annual temperature of $18.1^{\circ} \mathrm{C}$. The soil type is red soil according to the Chinese soil classification system, which is in the Plinthosol soil group according to the IUSS classification system ${ }^{19}$. The parent materials are quaternary red clay with kaolinite, the dominant mineral. The slope of the experimental field was $5^{\circ}$. Prior to conducting the experiment, the soil characteristics of the plough horizon $(0-20 \mathrm{~cm})$ were obtained and were as follows: the $\mathrm{pH}$ was 4.92 ; the soil organic carbon content was $11.3 \mathrm{~g} \mathrm{~kg}^{-1}$; and the total nitrogen and nitrate nitrogen contents were $0.95 \mathrm{~g} \mathrm{~kg}^{-1}$ and $8.55 \mathrm{mg} \mathrm{kg}^{-1}$, respectively.

Experimental design. The field experiment was conducted in both 2017 and 2018. There were seven treatments, N0, N60, N120, N150, N180, N210, and N240, with increasing rates of nitrogen fertilizer: 0, 60 (the lowest rate used by local farmers), 120,150, 180,210, and $240 \mathrm{~kg} \mathrm{ha}^{-1}$ (the highest rate used by local farmers), respectively. The seven treatments were randomized following a complete block design with three replicates. The plots were $30 \mathrm{~m}^{2}$ with a $6 \mathrm{~m}$ length and $5 \mathrm{~m}$ width.

Phosphorus $\left(\mathrm{P}_{2} \mathrm{O}_{5}\right)$ and potassium $\left(\mathrm{K}_{2} \mathrm{O}\right)$ fertilizers were applied in the respective amounts of 65 and $116 \mathrm{~kg} \mathrm{ha}^{-1}$ to all treatments. The kinds of nitrogen, phosphorus and potassium fertilizers were urea, calcium magnesium phosphate and potassium chloride, respectively. We added a mixture of $40 \%$ nitrogen, $100 \%$ phosphorus and $50 \%$ potassium fertilizer to the topsoil $(0-20 \mathrm{~cm})$ as basal fertilizer before planting potatoes. At the seedling stage (35 days after potato planting), 30\% nitrogen fertilizer was spread onto the soil surface. At the flowering stage (60 days after potato planting), 30\% nitrogen fertilizer and $50 \%$ potassium fertilizer were spread onto the soil surface.

The planting density was 4,200 plants $\mathrm{ha}^{-1}$, the sowing dates in 2017 and 2018 were the 22nd and 25th of February, and the harvest dates were the 18th and 22nd of May in 2017 and 2018. The row and plant spacing of potato were $30 \mathrm{~cm}$ and $20 \mathrm{~cm}$, respectively. We used the ridge cultivation system to plant potatoes; ridges were $35 \mathrm{~cm}$ in height and spaced $60 \mathrm{~cm}$ apart.

All experiments were performed in accordance with relevant guidelines and regulations. Moreover, we obtained permission to collect potato plants from the Jiangxi Institute of Red Soil.

Measurements. After harvesting plant materials in 2017 and 2018, potato tubers were manually excavated from each plot, collected and weighed to obtain tuber yield. Five plants were sampled from each plot, divided into tuber and straw, dried in an oven at $105^{\circ} \mathrm{C}$ for $2 \mathrm{~h}$, and then dried to a constant weight at $85^{\circ} \mathrm{C}$. The tubers and straw were pulverized by a micro plant grinding machine (model JFSO-480, Zhejiang Top Instrument Co., Ltd., Zhejiang Province, China) and then sieved manually through a $0.5-\mathrm{mm}$ mesh.

The nitrogen contents of the plant samples were determined by the micro-Kjeldahl method ${ }^{20}$. Potato nitrogen uptake and the apparent nitrogen balance were calculated using the following equations:

$$
\begin{gathered}
N_{\text {uptake }}=N_{\text {tuber }} \times Y_{\text {tuber }}+N_{\text {straw }} \times Y_{\text {straw }} \times 0.001 \\
N_{\text {balance }}=N_{\text {input }}-N_{\text {uptake }}
\end{gathered}
$$


where $\boldsymbol{N}_{\text {uptake }}$ is nitrogen uptake $\left(\mathrm{kg} \mathrm{ha}^{-1}\right) ; \boldsymbol{N}_{\text {tuber }}$ and $\boldsymbol{N}_{\text {straw }}$ are the nitrogen contents in tuber and straw materials $\left(\mathrm{g} \mathrm{kg}^{-1}\right)$, respectively; $\boldsymbol{Y}_{\text {tuber }}$ and $\boldsymbol{Y}_{\text {straw }}$ are the biomass yields of tubers and straw $\left(\mathrm{kg} \mathrm{ha}^{-1}\right)$, respectively; and $N_{\text {balance }}$ and $\boldsymbol{N}_{\text {input }}$ are apparent nitrogen balance and nitrogen fertilizer input $\left(\mathrm{kg} \mathrm{ha}^{-1}\right)$, respectively.

After plants were harvested in 2017 and 2018, soil samples at different depths $(0-20,20-40$ and $40-60 \mathrm{~cm})$ were collected. Five samples were collected from each plot using a shovel, and these samples were then mixed together to obtain one homogeneous sample per plot. In addition, three undisturbed soil cores $(5 \mathrm{~cm}$ in diameter, $5.1 \mathrm{~cm}$ in height) were taken from each of the three soil depths of each treatment to determine the soil bulk density. Any visible roots, organic residues, and stone fragments were removed manually from all fresh samples.

The nitrate nitrogen in the soil was extracted with $2 \mathrm{M} \mathrm{KCl}$ and quantified using a continuous flow injection analyser (model: Proxima, ALLIANCE Company, France). Nitrate nitrogen stocks at the different soil depths were calculated as follows: the nitrogen contents of the plant samples were determined by the micro-Kjeldahl method ${ }^{20}$. Potato nitrogen uptake and the apparent nitrogen balance were calculated using the following equations:

$$
\begin{gathered}
N N S_{0-20}=N N C_{0-20} \times B D_{0-20} \times 0.2 \times 0.1 \\
N N S_{20-40}=N N C_{20-40} \times B D_{20-40} \times 0.2 \times 0.1 \\
N N S_{40-60}=N N C_{40-60} \times B D_{40-60} \times 0.2 \times 0.1 \\
N N S_{0-60}=N N S_{0-20}+N N S_{20-40}+N N S_{40-60}
\end{gathered}
$$

where $\boldsymbol{N} N \boldsymbol{S}_{0-20}, \boldsymbol{N} N \boldsymbol{S}_{20-40}$, and $\boldsymbol{N} \boldsymbol{N} \boldsymbol{S}_{40-60}$ are the nitrate nitrogen stocks $\left(\mathrm{kg} \mathrm{ha}^{-1}\right)$ of the 0-20-, 20-40-, and 40-60-cm soil samples, respectively. $N N_{0-20}, N N C_{20-40}$, and $N N C_{40-60}$ are the nitrate-nitrogen contents $\left(\mathrm{mg} \mathrm{kg}^{-1}\right.$ ) of the 0-20-, 20-40- and 40-60-cm soil samples, respectively. $\boldsymbol{B} \boldsymbol{D}_{0-20}, \boldsymbol{B D}_{20-40}$, and $\boldsymbol{B} \boldsymbol{D}_{40-60}$ are the respective bulk density $\left(\mathrm{g} \mathrm{cm}^{-3}\right)$ values of the same three soil samples. In addition, $\boldsymbol{N} \boldsymbol{N} \boldsymbol{S}_{0-60}$ is the nitrate nitrogen stock $\left(\mathrm{kg} \mathrm{ha}^{-1}\right)$ of the total soil depth of 0-60 cm, which was the sum of $N N S_{0-20}, N N S_{20-40}$, and $N N S_{40-60}$.

Data analysis. Analysis of variance was performed using SPSS 19 software. The least significant difference (LSD at $\mathrm{P}<0.05)$ test was applied to assess the differences in means $(n=3)$ among treatments. The relationship between tuber yield and nitrogen rate was fitted by a parabolic equation. The relationships between nitrate nitrogen stocks at different soil depths $(0-20,20-40$ and $40-60 \mathrm{~cm})$ and the apparent nitrogen balance were fitted by exponential equations. Last, the relationship between the nitrate nitrogen stock at the $0-60-\mathrm{cm}$ soil depth and the apparent nitrogen balance was fitted by double linear equations. All figures were generated using Origin 8.5.

\section{Results}

Tuber yield. Potato tuber yield increased gradually under 0 to $150 \mathrm{~kg} \mathrm{ha}^{-1}$ of applied nitrogen (Fig. 1). Compared with the yield in N0, the yields in N60, N120 and N150 were greater by $16.1 \%, 21.5 \%$ and $67.9 \%$, respectively, in 2017 and $18.2 \%, 27.4 \%$ and $44.9 \%$, respectively, in 2018. However, at nitrogen rates of more than $150 \mathrm{~kg} \mathrm{ha}^{-1}$, yield did not significantly differ. Furthermore, the fitted parabolic equation of each dataset from 2017 and 2018 showed maximum tuber yields of 19.7 and $20.4 \mathrm{t} \mathrm{ha}^{-1}$, respectively, where the nitrogen rates were 191 and $227 \mathrm{~kg} \mathrm{ha}^{-1}$, respectively.

Potato nitrogen uptake. Nitrogen uptake in potato differed among all the treatments (Table 1). In both 2017 and 2018, the highest nitrogen uptake was attained in the N240 treatment, and the lowest uptake was attained in the N0 treatment. Compared with that in N0, the uptake levels measured in the N60, N120, N150, $\mathrm{N} 180, \mathrm{~N} 210$ and N240 treatments were greater by $61.2 \%, 100 \%, 115 \%, 144 \%, 142 \%$ and $237 \%$, respectively, in 2017. Meanwhile, the uptake levels measured in the N60, N120, N150, N180, N210 and N240 treatments were greater than that in the N0 treatment by 76.4\%, 98.5\%, 142\%, 198\%, 190\% and 284\%, respectively, for 2018. There were no significant differences among the N120, N150, N180 and N210 treatments in 2017. There were also no significant differences among the N150, N180 and N210 treatments in 2018.

Apparent nitrogen balance. The apparent nitrogen balance in potato production in red soil increased with increasing nitrogen application rates (Fig. 2). For both 2017 and 2018, all treatments with nitrogen application exhibited a surplus of nitrogen, while the N0 treatment exhibited a deficiency of nitrogen (18.6 and $18.0 \mathrm{~kg} \mathrm{ha}^{-1}$ in 2017 and 2018, respectively). Furthermore, the surplus was highest in the N240 treatment. Compared with that in the N60 treatment, the nitrogen surplus levels in the N120, N150, N180, N210 and N240 treatments were 176\%, 266\%, 348\%, 450\% and 490\% greater in 2017 and $198 \%, 277 \%, 347 \%, 459 \%$ and $505 \%$ greater in 2018, respectively.

Nitrate nitrogen content and stock at different soil depths. Nitrogen application increased the nitrate nitrogen content at all three depths of soil samples (Fig. 3). Generally, as nitrogen fertilizer rates increased, the nitrate nitrogen content increased in both 2017 and 2018 samples. For the same treatments among the three depths of soil in 2017, there were no significant differences in nitrate nitrogen contents. The result for 2018 was similar to that for 2017, with the exceptions of the N210 and N240 treatments, both of which showed higher nitrate nitrogen contents at $20-40 \mathrm{~cm}$ than at $0-20$ and $20-40 \mathrm{~cm}$. The nitrate nitrogen contents in N210 and N240 were higher than the contents in the other treatments among the three soil depths. Compared with the content in the N0 treatment, the nitrate nitrogen contents at $0-20 \mathrm{~cm}$ in the N210 and N240 treatments were $185 \%$ and $193 \%$ greater in 2017 and $218 \%$ and $268 \%$ greater in 2018, respectively. The nitrate nitrogen contents 


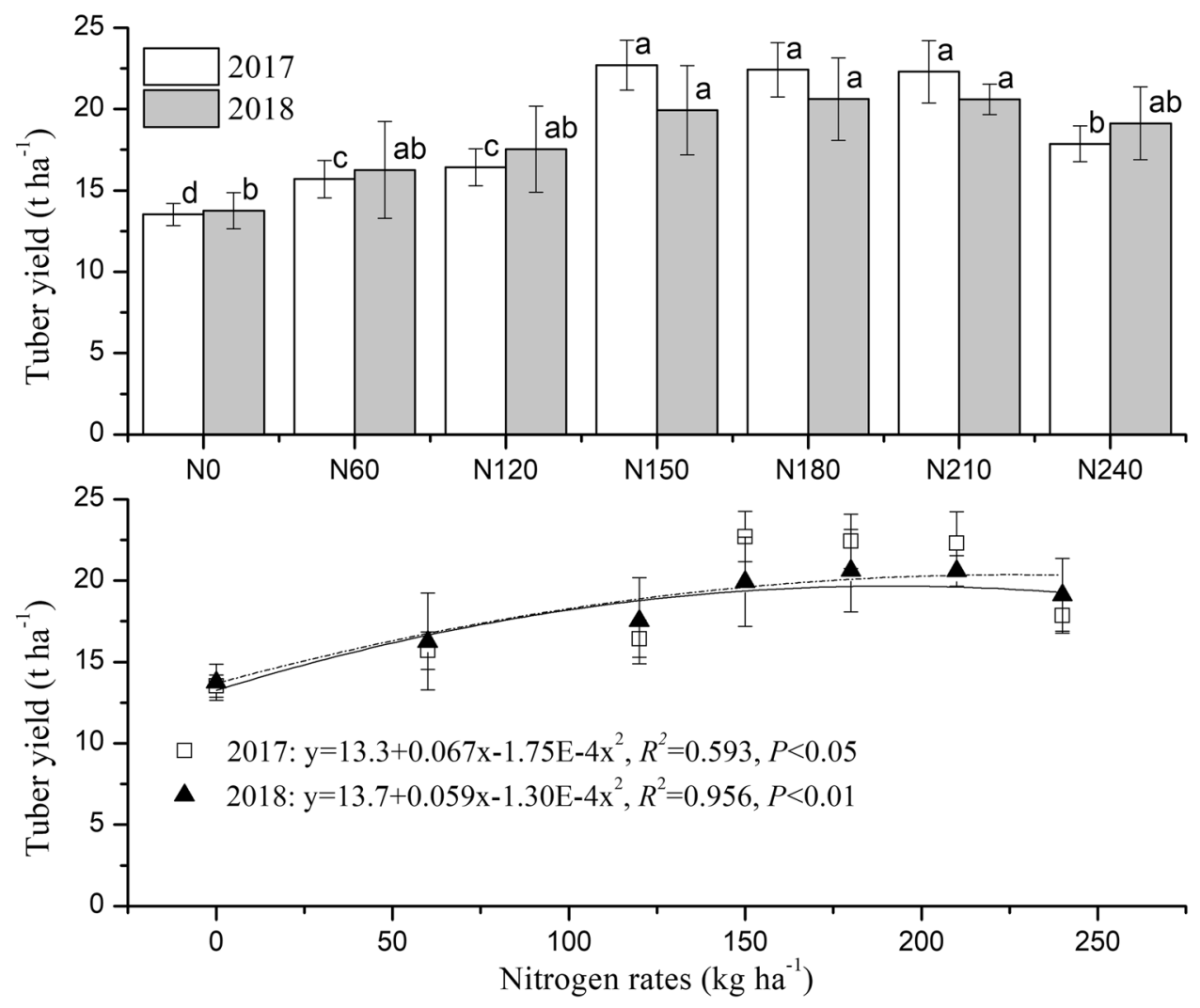

Figure 1. Potato tuber yield in treatments with different nitrogen fertilizer rates. Different letters indicate significant differences $(\mathrm{P}<0.05)$ among treatments in the same year.

\begin{tabular}{|l|l|l|}
\hline \multirow{2}{*}{ Treatments } & \multicolumn{2}{|l|}{ Nitrogen uptake $\left(\mathrm{kg} \mathrm{ha}^{-1}\right)$} \\
\cline { 2 - 3 } & $\mathbf{2 0 1 7}$ & $\mathbf{2 0 1 8}$ \\
\hline N0 & $18.6 \pm 3.58 \mathrm{~d}$ & $18.0 \pm 3.04 \mathrm{~d}$ \\
\hline N60 & $30.0 \pm 6.15 \mathrm{c}$ & $31.8 \pm 7.86 \mathrm{c}$ \\
\hline N120 & $37.2 \pm 5.71 \mathrm{~b}$ & $35.7 \pm 5.03 \mathrm{c}$ \\
\hline N150 & $39.9 \pm 3.72 \mathrm{~b}$ & $43.7 \pm 3.81 \mathrm{~b}$ \\
\hline N180 & $45.4 \pm 6.06 \mathrm{~b}$ & $53.7 \pm 4.04 \mathrm{ab}$ \\
\hline N210 & $44.9 \pm 1.79 \mathrm{~b}$ & $52.3 \pm 4.56 \mathrm{ab}$ \\
\hline N240 & $62.7 \pm 5.42 \mathrm{a}$ & $69.1 \pm 5.06 \mathrm{a}$ \\
\hline
\end{tabular}

Table 1. Nitrogen uptake in potato applied with treatments of different nitrogen fertilizer rates. Different letters indicate significant differences $(\mathrm{P}<0.05)$ among treatments in the same year.

at $20-40 \mathrm{~cm}$ in the N210 and N240 treatments were $186 \%$ and $188 \%$ greater in 2017 and $339 \%$ and $367 \%$ greater in 2018, respectively. The nitrate nitrogen contents at $40-60 \mathrm{~cm}$ in the N210 and N240 treatments were $209 \%$ and $271 \%$ higher in 2017 and $212 \%$ and $318 \%$ higher in 2018 , respectively.

There was less consistency in significant differences in nitrate nitrogen content among treatments with less than $210 \mathrm{~kg} \mathrm{ha}^{-1}$ nitrogen fertilizer applied. In the 2017 samples, no significant differences were observed among N0, N60, N120, N150 and N180, with the exception of the nitrate nitrogen content in N180 being higher than those in N0, N60, N120, and N150 at the $0-20-\mathrm{cm}$ soil depth. In the 2018 samples, the nitrate nitrogen contents in $\mathrm{N} 180$ and $\mathrm{N} 150$ were higher than those in N0, N60, and N120 at the $0-20$ - and 20-40-cm soil depths. In contrast, the nitrate nitrogen content in the N180 treatment at the $40-60-\mathrm{cm}$ soil depth was not lower than that in the N240 and N210 treatments. Additionally, no significant differences were observed at the 40-60-cm depth among the $\mathrm{N} 0, \mathrm{~N} 60$, and N120 treatments, but the nitrate nitrogen contents of the N150 and N180 treatments were higher than the content of the N0 treatment by $57.3 \%$ and $111 \%$ in 2017 and by $147 \%$ and $234 \%$ in 2018 , respectively.

The nitrate nitrogen stock results were similar to the nitrate nitrogen content results. Table 2 shows that there were no significant differences in nitrate nitrogen stock among the three depths of soil in 2017. In 2018, the nitrate nitrogen stocks at $20-40 \mathrm{~cm}$ were higher than those at $0-20$ and $20-40 \mathrm{~cm}$. Compared with those in 


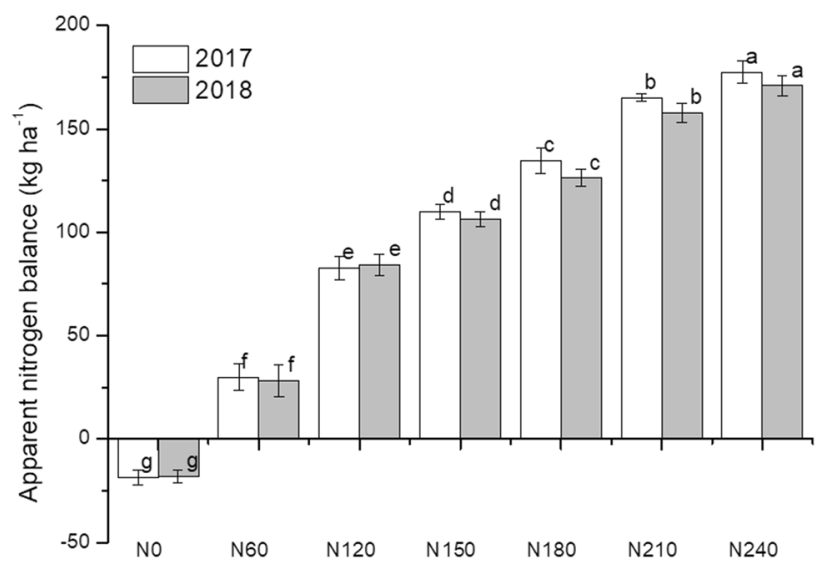

Figure 2. Apparent nitrogen balance (amount of nitrogen input minus amount of plant nitrogen uptake) calculated for potato treated with different nitrogen fertilizer rates. Different letters indicate significant differences $(\mathrm{P}<0.05)$ among treatments in the same year.
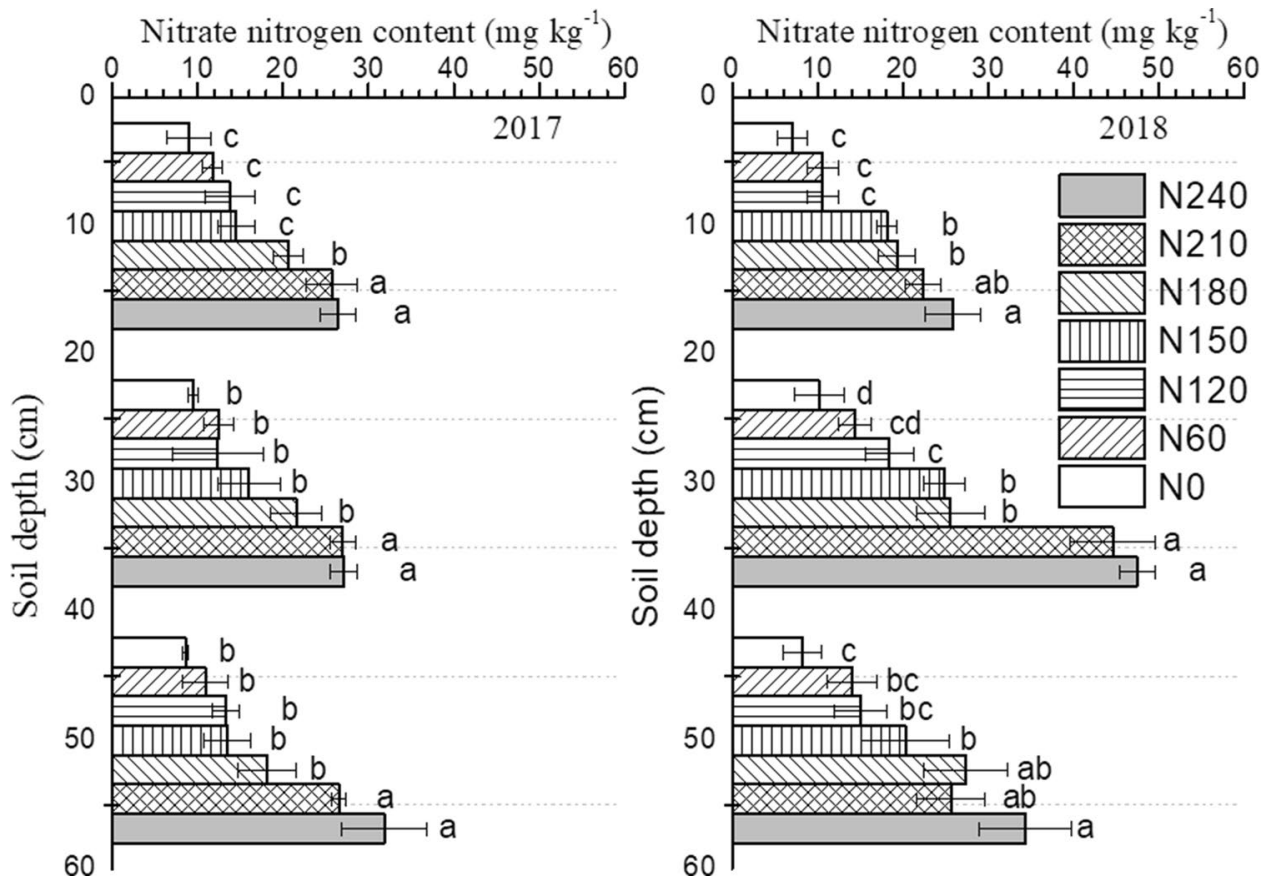

Figure 3. Nitrate nitrogen contents at different soil depths in treatments with different nitrogen fertilizer rates. Different letters in the same soil depth indicate significant differences $(\mathrm{P}<0.05)$ among treatments in the same year. Nitrogen balance (amount of nitrogen input minus amount of plant nitrogen uptake) calculated for potato treated with different nitrogen fertilizer rates.

2017, the nitrate nitrogen stocks at 0-60 cm (sum of measurements from the three depths) in 2018 were greater due to the application of nitrogen fertilizer. The nitrate nitrogen stock was higher in the nitrogen application treatments among the three soil depths than in the no-nitrogen fertilizer treatment (Table 2). A general trend of higher levels was also observed in the N210 and N240 treatments compared with the other treatments. The nitrate nitrogen stock at $0-60 \mathrm{~cm}$ was greater in the $\mathrm{N} 210$ and $\mathrm{N} 240$ treatments than in the N180 treatment by $31.6 \%$ and $41.6 \%$ in 2017 , respectively, and $30.5 \%$ and $51.6 \%$ in 2018 , respectively. For the three soil depths in 2017, there were no significant differences among the N0, N60, N120 and N150 treatments, but their nitrogen stocks were lower than that of the N180 treatment (except for that at the 40-60 cm depth). The results in 2018 revealed no significant differences among the N0, N60 and N120 treatments, but their nitrogen stocks were all lower than those in the N150 and N180 treatments.

The relationship between the apparent nitrogen balance and nitrate nitrogen stock. The nitrate nitrogen stock at the 0-20-, 20-40- and 40-60-cm soil depths increased exponentially with the apparent 


\begin{tabular}{|c|c|c|c|c|c|}
\hline \multirow[b]{2}{*}{ Year } & \multirow[b]{2}{*}{ Treatments } & \multicolumn{4}{|c|}{ Nitrate nitrogen stock at different soil depths (kg ha-1) } \\
\hline & & $0-20-\mathrm{cm}$ & $20-40-\mathrm{cm}$ & $40-60-\mathrm{cm}$ & $0-60-\mathrm{cm}$ \\
\hline \multirow{7}{*}{2017} & N0 & $29.0 \pm 8.19 \mathrm{c}$ & $27.8 \pm 1.84 \mathrm{c}$ & $21.8 \pm 0.91 \mathrm{c}$ & $78.7 \pm 11.0 \mathrm{c}$ \\
\hline & N60 & $35.7 \pm 3.72 \mathrm{c}$ & $36.2 \pm 4.90 \mathrm{c}$ & $26.4 \pm 6.58 \mathrm{c}$ & $98.2 \pm 15.2 \mathrm{c}$ \\
\hline & N120 & $43.6 \pm 9.32 \mathrm{c}$ & $36.3 \pm 15.7 \mathrm{c}$ & $33.4 \pm 3.79 c$ & $113 \pm 28.8 \mathrm{c}$ \\
\hline & N150 & $45.6 \pm 6.82 \mathrm{c}$ & $46.8 \pm 10.7 \mathrm{bc}$ & $33.8 \pm 6.85 c$ & $126 \pm 24.4 \mathrm{c}$ \\
\hline & N180 & $63.1 \pm 5.39 \mathrm{~b}$ & $62.9 \pm 8.73 \mathrm{~b}$ & $44.6 \pm 8.55 c$ & $171 \pm 22.7 \mathrm{~b}$ \\
\hline & $\mathrm{N} 210$ & $80.2 \pm 9.33 a$ & $78.4 \pm 4.36 \mathrm{a}$ & $65.9 \pm 2.04 \mathrm{~b}$ & $224 \pm 15.7 \mathrm{a}$ \\
\hline & $\mathrm{N} 240$ & $82.4 \pm 6.35 \mathrm{a}$ & $79.4 \pm 4.68 \mathrm{a}$ & $79.7 \pm 12.5 \mathrm{a}$ & $241 \pm 23.5 \mathrm{a}$ \\
\hline \multirow{7}{*}{2018} & No & $22.6 \pm 5.55 c$ & $29.9 \pm 8.61 \mathrm{c}$ & $20.9 \pm 5.84 \mathrm{c}$ & $73.4 \pm 20.0 \mathrm{c}$ \\
\hline & N60 & $32.2 \pm 5.65 \mathrm{c}$ & $41.6 \pm 5.39 \mathrm{c}$ & $33.9 \pm 7.00 \mathrm{bc}$ & $108 \pm 18.0 \mathrm{c}$ \\
\hline & N120 & $33.4 \pm 5.83 \mathrm{c}$ & $54.2 \pm 8.34 \mathrm{c}$ & $37.6 \pm 7.78 \mathrm{bc}$ & $125 \pm 22.0 \mathrm{c}$ \\
\hline & N150 & $56.9 \pm 3.59 \mathrm{~b}$ & $72.6 \pm 6.96 \mathrm{~b}$ & $50.7 \pm 12.9 \mathrm{~b}$ & $180 \pm 23.4 \mathrm{~b}$ \\
\hline & N180 & $59.2 \pm 6.67 \mathrm{~b}$ & $74.7 \pm 11.5 \mathrm{~b}$ & $67.5 \pm 12.1 \mathrm{ab}$ & $201 \pm 30.3 b$ \\
\hline & $\mathrm{N} 210$ & $69.8 \pm 6.45 \mathrm{ab}$ & $129 \pm 14.7 \mathrm{a}$ & $63.6 \pm 9.84 \mathrm{ab}$ & $263 \pm 31.0 \mathrm{a}$ \\
\hline & N240 & $80.7 \pm 9.90 \mathrm{a}$ & $139 \pm 6.13 \mathrm{a}$ & $86.0 \pm 13.5 \mathrm{a}$ & $305 \pm 29.6 \mathrm{a}$ \\
\hline
\end{tabular}

Table 2. Nitrate nitrogen stock at different soil depths in treatments with different nitrogen fertilizer rates. Different letters at the same soil depth indicate significant differences $(\mathrm{P}<0.05)$ among treatments in the same year.

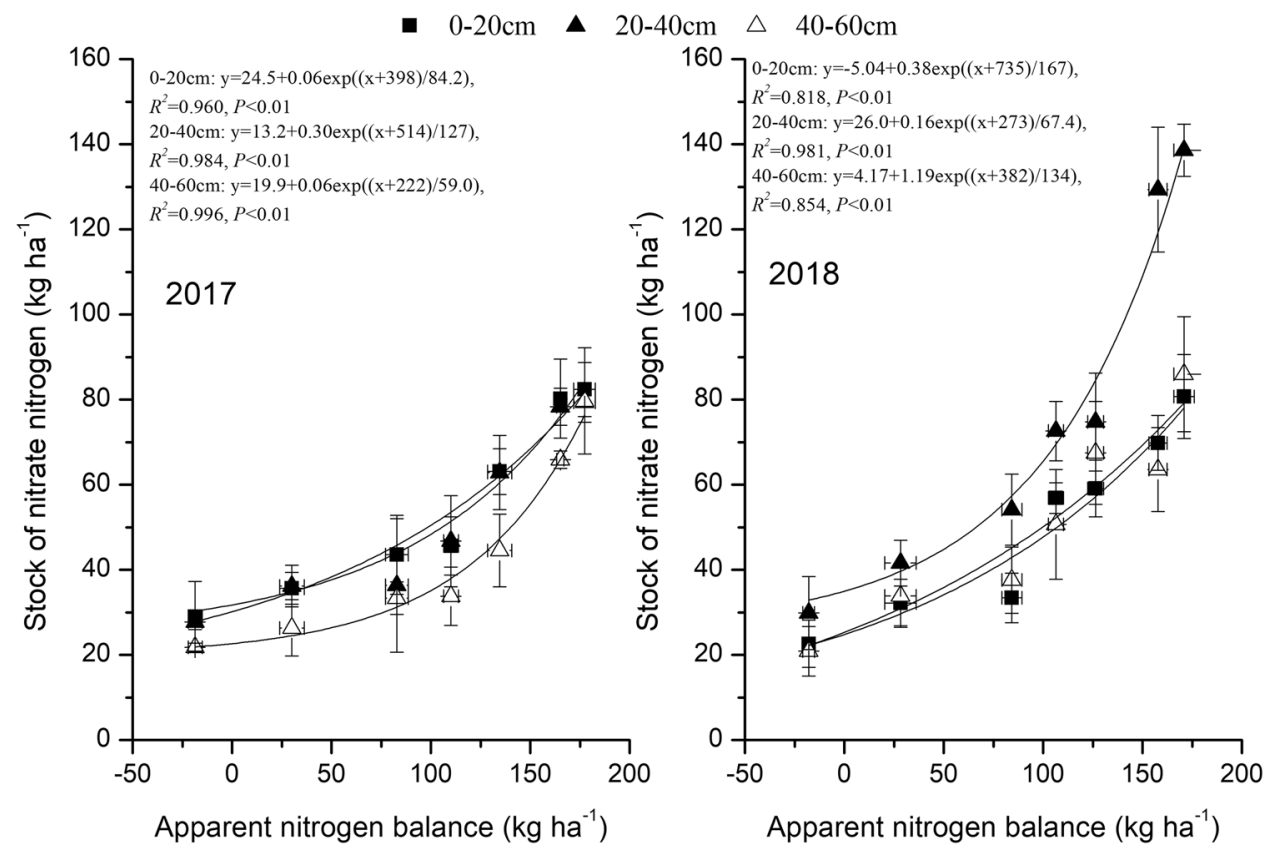

Figure 4. The relationship between the apparent nitrogen balance and nitrate nitrogen stock at different soil depths.

nitrogen balance (Fig. 4). The relationship at each of the three depths showed a gradual rate of increase in the nitrate nitrogen stock as the values calculated for the apparent nitrogen balance increased.

The relationship between the apparent nitrogen balance and nitrate nitrogen stock at the $0-60-\mathrm{cm}$ soil depth was fitted by double linear equations in both 2017 and $2018(\mathrm{P}<0.01$, Fig. 5). The rates of increase in nitrate nitrogen stocks in 2017 and 2018 were 0.34 and $0.50 \mathrm{~kg} \mathrm{ha}^{-1}$, respectively, as the apparent nitrogen balance increased up to 100 and $94.3 \mathrm{~kg} \mathrm{ha}^{-1}$, respectively. However, beyond those values of the apparent nitrogen balance, the slopes of the equations were steeper, indicating faster rates of increase for 2017 and 2018 at 1.73 and $1.92 \mathrm{~kg} \mathrm{ha}^{-1}$, respectively. 


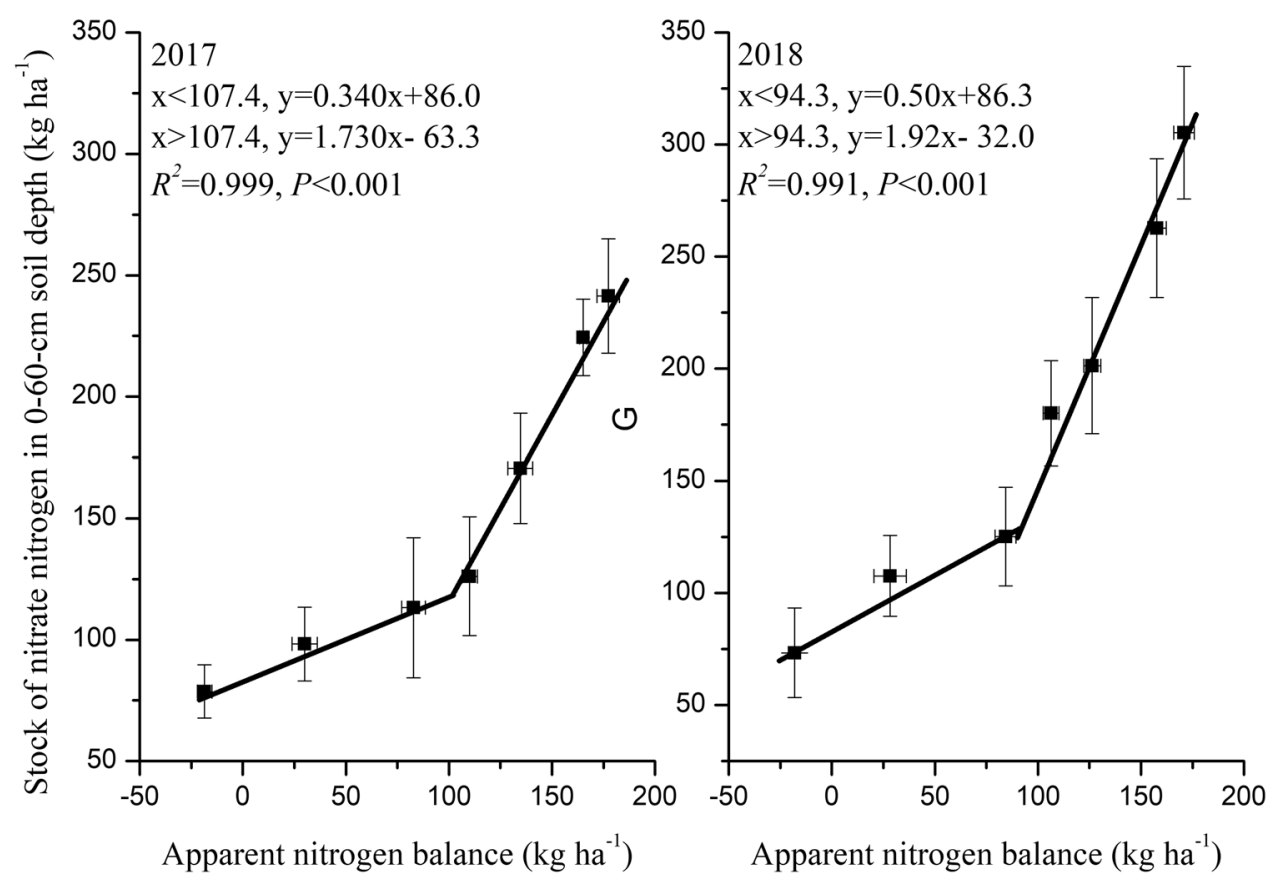

Figure 5. The relationship between the apparent nitrogen balance and nitrate nitrogen stock at the total soil depth of $0-60 \mathrm{~cm}$.

\section{Discussion}

Tuber yield, nitrogen uptake and apparent nitrogen balance increased with increasing rates of nitrogen application to red soil. In general, the natural supply of nitrogen in red soil is inadequate to support the production of crops $^{21}$, so the application of nitrogen fertilizer has been necessary to meet the demands for higher crop yields ${ }^{22}$. Unlike in the western region of China, a threshold rate of nitrogen fertilizer application has yet to be determined for potato planting in red soil ${ }^{2-4}$. In this study, potato yield increased with increasing amounts of applied nitrogen fertilizer. This result was similar to other findings ${ }^{11,14,16,18}$. In addition, we estimated that maximum tuber yields of 19.7 and $20.4 \mathrm{t} \mathrm{ha}^{-1}$ could be attained with nitrogen application rates to red soil of 191-227 $\mathrm{kg} \mathrm{ha}^{-1}$. However, our tuber yields were lower than those observed in other regions ${ }^{11,15,16,18}$; for example, at the provincial level in China, Wang et al. ${ }^{15}$ used two crop growth models and estimated potato yields to vary from $38.8 \mathrm{t} \mathrm{ha}^{-1}$ to $66.4 \mathrm{t} \mathrm{ha}^{-1}$ in $2006-2015$. In addition to the potential effect of crop varieties, the likely reason for our lower yield estimates in red soil is the inherent lower soil fertility ${ }^{23}$ than that observed in the western region of China. Additionally, the higher proportion of clay in red soil ${ }^{23,24}$, which indicates poor soil structure, likely suppressed tuber enlargement of the potatoes grown in that type of soil. Potatoes grow better in soils with less clay and a more developed soil structure ${ }^{25}$. A second possible factor affecting yield is the rainfall that occurs in spring, when potato vegetative growth primarily occurs. More rainfall suggests a greater presence of clouds that reduce the amount of sunlight reaching potato leaves, resulting in reduced photosynthetic activity and in turn limiting tuber production to meet higher yields. However, for the red soil region, there were different rainfall patterns and air temperatures at different sites, and their soil fertility levels varied. Therefore, the threshold rate of nitrogen application for higher potato tuber yields in this study will be further verified at other sites.

Other nutrient deficiencies can affect nitrogen deficiency in soil. Grzebisz et al. ${ }^{26}$ reported that increased amounts of potassium in tubers at harvest might be a crucial factor for controlling the partial factor productivity of fertilizer nitrogen, subsequently decreasing nitrogen rates. Red soil is potassium deficient ${ }^{27}$; therefore, we suggest that application rates of potassium fertilizer should also be optimized towards specific production goals.

In the red soil, nitrogen uptake in potato increased gradually with increasing nitrogen application rates $\left(0-240 \mathrm{~kg} \mathrm{ha}^{-1}\right)$ to the soil. However, the nitrogen uptake by potato in our study was lower than that reported for potato grown in the western region of China and was likely due to the lower biomass observed in our study ${ }^{4}$.

Higher inputs of nitrogen fertilizer can lead to a nitrogen surplus in red soil, although some nitrogen may be removed by severe soil erosion resulting from rainfall ${ }^{6,14}$. We found that the amount of nitrogen surplus was more than $25 \mathrm{~kg} \mathrm{ha}^{-1}$ among all nitrogen fertilization treatments. Moreover, the amounts were much higher, more than $150 \mathrm{~kg} \mathrm{ha}^{-1}$, in the treatments with the highest nitrogen rates, 210 and $240 \mathrm{~kg} \mathrm{ha}^{-1}$. However, the amounts of nitrogen surplus differed from those at other sites reported in other studies, and the differences were likely due to soil type, type and variety of crop, and other factors. Because a higher nitrogen surplus increases nitrogen pollution risk via runoff and leachates ${ }^{28}$, to reduce the risk from the excess nitrogen in the soil, we recommend a rotation of another crop, such as maize, in the same fields after the potatoes are harvested. 
Nitrate nitrogen content and stock increased with increasing nitrogen rates applied to red soil. The ridge cultivation system is commonly used in potato cultivation ${ }^{14}$. Because of this system, most of the applied nitrogen fertilizer was likely mixed into the soil to a depth of approximately $55 \mathrm{~cm}$; the ridge height was approximately $35 \mathrm{~cm}$ plus a $20-\mathrm{cm}$ tillage layer. Our results illustrated that there were no significant differences in nitrate nitrogen contents and stocks among the three depths of soil in 2017, indicating that the nitrogen fertilizer was likely well homogenized to at least a $60 \mathrm{~cm}$ soil depth. In the 2018 samples, the nitrate nitrogen contents at the $20-40 \mathrm{~cm}$ depth in the N210 and N240 treatments were higher than those at the $0-20$ and $20-40 \mathrm{~cm}$ depths. The nitrate nitrogen stocks at $20-40 \mathrm{~cm}$ in all treatments were higher than those at $0-20 \mathrm{~cm}$ and $20-40 \mathrm{~cm}$. We attribute these patterns in stock amounts and soil depth to the fact that potatoes were planted at a depth of approximately $30 \mathrm{~cm}$ in the ridge cultivation system, and all the nitrate nitrogen from the urea fertilizer was likely absorbed by the roots, moving the nitrogen to the $30-\mathrm{cm}$ depth of soil ${ }^{29}$.

Soil nitrate nitrogen availability prior to the application of nitrogen fertilizer is also an important factor affecting plant nitrogen use efficiency ${ }^{30}$. In a novel aeroponics system, Tiwari et al ${ }^{31}$ found that plant nitrogen availability was greater under controlled conditions with high nitrogen $\left(7.5 \mathrm{mmol} \mathrm{L}^{-1}\right.$ nitrate nitrogen) levels than under those with low nitrogen $\left(0.75 \mathrm{mmol} \mathrm{L}^{-1}\right.$ nitrate nitrogen) levels. Between the two years of soil sampling, the 2018 samples contained higher nitrate nitrogen stocks at $0-60 \mathrm{~cm}$ in all nitrogen fertilization treatments than the 2017 samples. The higher level in the second year was probably due to residual nitrogen fertilizer unused from the previous year ${ }^{32}$. After nitrogen fertilization application, some of the nitrogen will be absorbed by the crop, and the rest of the applied nitrogen may stay in a reserve at $0-60-\mathrm{cm}$ soil depth in the form of nitrate nitrogen, likely from the applied urea.

Our data showed that the nitrate nitrogen content and stock increased significantly with increasing nitrogen application rates. Our result was consistent with that of Woli et al. ${ }^{11}$. Using a meta-analysis, Cui et al. ${ }^{33}$ also found that both reactive nitrogen losses and total $\mathrm{N}_{2} \mathrm{O}$ emissions from nitrogen fertilization increased exponentially with an increasing nitrogen application rate. However, the more nitrate nitrogen unabsorbed by roots and found in the soil, the more nitrogen may leach from the soil and pollute groundwater ${ }^{34}$.

The response of nitrate nitrogen stocks to the apparent nitrogen balance of potato under different nitrogen application rates. Our results suggest a positive exponential relationship between nitrogen surplus and the soil nitrate nitrogen stock, as indicated by the gradual increase in the nitrate nitrogen stock with the increase in the apparent nitrogen balance. Moreover, the double linear equations of this relationship suggest that the turning point from a gradual to a steep increase in nitrogen surplus levels occurred at an apparent nitrogen balance of approximately $94.3-100 \mathrm{~kg} \mathrm{ha}^{-1}$. The rate of increase in the nitrate nitrogen stock was $1.73-1.92 \mathrm{~kg} \mathrm{ha}^{-1}$ at the total soil depth of $0-60 \mathrm{~cm}$. When the nitrogen surplus rose above $94.3-100 \mathrm{~kg} \mathrm{ha}^{-1}$, the stock was higher than that $\left(0.34-0.50 \mathrm{~kg} \mathrm{ha}^{-1}\right)$ when the nitrogen surplus was less than $94.3-100 \mathrm{~kg} \mathrm{ha}^{-1}$. This result was consistent with the relationship between soil nitrate nitrogen levels and potato yield reported by Nurmanov et al. ${ }^{30}$. In the dark chestnut heavy loamy soils of central Kazakhstan, Nurmanov et al ${ }^{30}$ found that the maximum possible potato yield was achieved when soil nitrate nitrogen was lower than $22 \mathrm{mg} \mathrm{kg}^{-130}$. Therefore, the $94.3-100 \mathrm{~kg} \mathrm{ha}^{-1}$ range of nitrogen surplus could be used as a point of reference for soil nitrate nitrogen management and nitrogen fertilization strategies aiming to the threshold rate of fertilizer application rates for potato production in red soil.

\section{Conclusions}

The threshold rate of nitrogen fertilizer applied to red soil for attaining high tuber yields in potato was estimated to be between 191 and $227 \mathrm{~kg} \mathrm{ha}^{-1}$. There was no significant increase in yield above $150 \mathrm{~kg} \mathrm{ha}^{-1}$ applied nitrogen fertilizer. The nitrogen balance passed a threshold of $100 \mathrm{~kg} \mathrm{ha}^{-1}$ at nitrogen fertilizer application rates above $150 \mathrm{~kg} \mathrm{ha}^{-1}$. A positive relationship between the apparent nitrogen balance and nitrogen application rate was observed. Above that threshold, the nitrate stock remaining in the soil increased dramatically, increasing the potential for nitrogen loss. For sustainable production in red soils, the rate of nitrogen fertilizer application should not exceed $150 \mathrm{~kg} \mathrm{ha}^{-1}$. Therefore, this research will be helpful for the sustainable productivity of potato in red soil.

\section{Data availability}

Data reported within the article.

Received: 28 August 2021; Accepted: 10 November 2021

Published online: 18 November 2021

\section{References}

1. Kloosterman, B. et al. Naturally occurring allele diversity allows potato cultivation in northern latitudes. Nature 495, 246-250. https://doi.org/10.1038/nature11912 (2013).

2. Wang, N., Reidsma, P., Pronk, A. A., de Wit, A. J. W. \& van Ittersum, M. K. Can potato add to China's food self-sufficiency? The scope for increasing potato production in China. Eur. J. Agron. 101, 20-29. https://doi.org/10.1016/j.eja.2018.07.002 (2018).

3. Huang, Z., Zuo, A., Sun, J. \& Guo, Y. Potato farmers' preference for agricultural insurance in China: An investigation using the choice experimental method. J. Integr. Agr. 19(4), 1137-1148. https://doi.org/10.1016/S2095-3119(19)62868-6 (2020).

4. Xu, Y. et al. Estimating nutrient uptake requirements for potatoes based on QUEFTS analysis in China. Agron. J. 111, 5. https:// doi.org/10.2134/agronj2018.09.0572 (2019).

5. Liu, K. \& Li, Y. Different response of grain yield to soil organic carbon, nitrogen, and phosphorus in red soil as based on the longterm fertilization experiment. Euras. Soil Sci. 51(12), 1507-1513. https://doi.org/10.1134/S1064229318130021 (2018).

6. Ma, W. et al. Effect of soil erosion on dissolved organic carbon redistribution in subtropical red soil under rainfall simulation. Geomorphology 2261, 217-225. https://doi.org/10.1016/j.geomorph.2014.08.017 (2014). 
7. Wang, L. et al. The potential for soil erosion control associated with socio-economic development in the hilly red soil region southern China. CATENA 194, 104678. https://doi.org/10.1016/j.catena.2020.104678 (2020).

8. Qiang, S. et al. Maize yield, rainwater and nitrogen use efficiency as affected by maize genotypes and nitrogen rates on the Loess Plateau of China. Agr. Water Manag. 2131, 996-1003. https://doi.org/10.1016/j.agwat.2018.12.021 (2019).

9. Chi, Y., Yang, P., Ren, S. \& Yang, J. Finding the optimal fertilizer type and rate to balance yield and soil GHG emissions under reclaimed water irrigation. Sci. Total Environ. 72910, 138954. https://doi.org/10.1016/j.scitotenv.2020.138954 (2020).

10. Liang, K. et al. Nitrogen dynamics and leaching potential under conventional and alternative potato rotations in Atlantic Canada. Field Crop Res. 2421, 107603. https://doi.org/10.1016/j.fcr.2019.107603 (2019).

11. Woli, P., Hoogenboom, G. \& Alva, A. Simulation of potato yield.; nitrate leaching.; and profit margins as influenced by irrigation and nitrogen management in different soils and production regions. Agr. Water Manag. 171, 120-130. https://doi.org/10.1016/j. agwat.2016.04.003 (2016).

12. Abdo, A. I., Elrys, A. S., Abdel-Fattah, M. K., Desoky, E. M. \& Wang, L. Mitigating nitrate accumulation in potato tubers under optimum nitrogen fertilization with K-humate and calcium chloride. J. Clean Prod. 25920, 121108. https://doi.org/10.1016/j.jclep ro.2020.121108 (2020).

13. Mueller, N. D. et al. Closing yield gaps through nutrient and water management. Nature 490(7419), 254-257. https://doi.org/10. 1038/nature11420 (2012).

14. Wang, X. et al. Exploring the optimization of water and fertilizer management practices for potato production in the sandy loam soils of Northwest China based on PCA. Agr. Water Manag. 2371, 106180. https://doi.org/10.1016/j.agwat.2020.106180 (2020).

15. Wang, H. et al. Multi-objective optimization of water and fertilizer management for potato production in sandy areas of northern China based on TOPSIS. Field Crop Res. 2401, 55-68. https://doi.org/10.1016/j.fcr.2019.06.005 (2019).

16. Rens, L. R., Zotarelli, L., Rowland, D. L. \& Morgan, K. T. Optimizing nitrogen fertilizer rates and time of application for potatoes under seepage irrigation. Field Crop Res. 215, 49-58. https://doi.org/10.1016/j.fcr.2017.10.004 (2018).

17. Saluzzo, J. A., Echeverría, H. E., Andrade, F. H. \& Huarte, M. Nitrogen nutrition of potato cultivars differing in maturity. J. Agron. Crop Sci. 183, 157-165. https://doi.org/10.1046/j.1439-037x.1999.00323.x (1999).

18. Fandika, I. R., Kemp, P. D., Millner, J. P., Horne, D. \& Roskruge, N. Irrigation and nitrogen effects on tuber yield and water use efficiency of heritage and modern potato cultivars. Agr. Water Manage. 17031, 148-157. https://doi.org/10.1016/j.agwat.2015.10. 027 (2016).

19. IUSS Working Group. World Reference Base for Soil Resources 2006 2nd edn. (Food and Agriculture Organization, 2006).

20. Lu, R. K. Analytical Methods for Soil and Agricultural Chemistry (China Agricultural Science and Technology Press, 2000) (in Chinese).

21. Duan, Y. et al. Nitrogen use efficiency in a wheat-corn cropping system from 15 years of manure and fertilizer applications. Field Crop Res. 15715, 47-56. https://doi.org/10.1016/j.fcr.2013.12.012 (2014).

22. Xia, H., Riaz, M., Zhang, M., Liu, B. \& Jiang, C. Biochar increases nitrogen use efficiency of maize by relieving aluminum toxicity and improving soil quality in acidic soil. Ecotox. Environ. Safe 19615, 110531. https://doi.org/10.1016/j.ecoenv.2020.110531 (2020).

23. Guo, Z. et al. Does animal manure application improve soil aggregation? Insights from nine long-term fertilization experiments. Sci. Total Environ. 66010, 1029-1037. https://doi.org/10.1016/j.scitotenv.2019.01.051 (2019).

24. Zhang, H., Xu, M. G. \& Zhang, F. D. Long-term effects of manure application on grain yield under different cropping systems and ecological conditions in China. J. Agr. Sci. 147, 31-42. https://doi.org/10.1017/S0021859608008265 (2019).

25. Reyes-Cabrera, J., Zotarelli, L., Dukes, M. D., Rowland, D. L. \& Sargent, S. A. Soil moisture distribution under drip irrigation and seepage for potato production. Agr. Water Manage. 169, 183-192. https://doi.org/10.1016/j.agwat.2016.03.001 (2016).

26. Grzebisz, W., Szczepaniak, W. \& Bocianowski, J. Potassium fertilization as a driver of sustainable management of nitrogen in potato (Solanum tuberosum L.). Field Crop Res. 2541, 1024. https://doi.org/10.1016/j.fcr.2020.107824 (2020).

27. Liu, K. et al. Response of soil aggregate-asociated potassium to long-term fertilization in red soil. Geoderma 352, 160-170. https:// doi.org/10.1016/j.geoderma.2019.06.007 (2019).

28. Wu, H. et al. Accumulation of nitrate and dissolved organic nitrogen at depth in a red soil Critical Zone. Geoderma 3371, 11751185. https://doi.org/10.1016/j.geoderma.2018.11.019 (2019).

29. Huang, J. et al. Nitrogen mobility, ammonia volatilization, and estimated leaching loss from long-term manure incorporation in red soil. J. Integr. Agr. 16, 2082-2092. https://doi.org/10.1016/S2095-3119(16)61498-3 (2017).

30. Nurmanov, Y. T., Chernenok, V. G. \& Kuzdanova, R. S. Potato in response to nitrogen nutrition regime and nitrogen fertilization. Field Crop Res. 2311, 115-121. https://doi.org/10.1016/j.fcr.2018.11.014 (2019).

31. Tiwari, J. K. et al. Precision phenotyping of contrasting potato (Solanum tuberosum L.) varieties in a novel aeroponics system for improving nitrogen use efficiency: In search of key traits and genes. J. Integra. Agr. 19(1), 51-61. https://doi.org/10.1016/S20953119(19)62625-0 (2020).

32. Quemada, M. et al. Residual effect of synthetic nitrogen fertilizers and impact on soil nitrifiers. Eur. J. Agron. 109, 125917. https:// doi.org/10.1016/j.eja.2019.125917 (2019).

33. Cui, Z. et al. Closing the N-use efficiency gap to achieve food and environmental security. Environ. Sci. Technol. 48(10), 5780-5787. https://doi.org/10.1021/es5007127 (2014).

34. Li, W. et al. The overlooked role of diffuse household livestock production in nitrogen pollution at the watershed scale. J. Clean Prod. 2721, 122758. https://doi.org/10.1016/j.jclepro.2020.122758 (2020).

\section{Author contributions}

Conceptualization, K.L.; methodology, K.L., J.D.; writing-original draft preparation, K.L., J.D.; writing-review and editing, Y.Z., Z.S.; funding acquisition, K.L., X.Y. All authors have read and agreed to the published version of the manuscript.

\section{Funding}

This research was supported by the project of Double Thousand Plan in Jiangxi Province of China (no. jxsq2020102116), the National Key Research and Development Program of China (2016YFD0200101), and the Natural Science Foundation of Jiangxi Province, China (20192BAB203022).

\section{Competing interests}

The authors declare no competing interests.

\section{Additional information}

Correspondence and requests for materials should be addressed to K.L.

Reprints and permissions information is available at www.nature.com/reprints. 
Publisher's note Springer Nature remains neutral with regard to jurisdictional claims in published maps and institutional affiliations.

(c) (i) Open Access This article is licensed under a Creative Commons Attribution 4.0 International License, which permits use, sharing, adaptation, distribution and reproduction in any medium or format, as long as you give appropriate credit to the original author(s) and the source, provide a link to the Creative Commons licence, and indicate if changes were made. The images or other third party material in this article are included in the article's Creative Commons licence, unless indicated otherwise in a credit line to the material. If material is not included in the article's Creative Commons licence and your intended use is not permitted by statutory regulation or exceeds the permitted use, you will need to obtain permission directly from the copyright holder. To view a copy of this licence, visit http://creativecommons.org/licenses/by/4.0/.

(C) The Author(s) 2021 